\title{
ICT or I See Tea? Modernity, Technology and Education in Nepal
}

\author{
Robin Shields \\ This is an author's version of the final text submitted for publication in: \\ Shields, R. (2011) ICT or I see tea? Modernity, technology and education in Nepal. Globalisation, \\ Societies and Education, 9 (1). pp. 85-97. ISSN 1476-7724
}

\begin{abstract}
The use of information and communications technology (ICT) for education in developing countries has been a subject of great interest and speculation, with its proponents arguing that ICT improves educational quality, develops critical thinking skills, expands access, increases economic competitiveness and facilitates inclusion in a rapidly expanding global information society. However, few of these claims have been verified from an empirical standpoint, leading to substantial criticism of the push to expand ICT. This article analyses how the global discourse on ICT in education has unfolded in Nepal, concentrating on educational policies on ICT and how these relate to a rather limited domain of practice. It argues that policies on ICT in education reveal an uneasy and fragmented engagement with the global discourse, while in practice its use is often innovative although so limited as to cause little substantive change. However, in both policy and practice the importance of ICT is more due its power as symbol of modernity and progress than any utilitarian value.
\end{abstract}

\section{Keywords}

Nepal, education, technology, ICT

\section{Correspondence}

School of Education, Bath Spa University, Newton St.-Loe, Bath BA2 9BD, United Kingdom

Email: r.shields@bathspa.ac.uk

\section{Biography}

Robin Shields' research investigates technology and information access in education and international development, with a regional specialisation in South Asia. He is a lecturer in education at Bath Spa University. 
While working at an international organisation in Kathmandu, I was cheerfully greeted each day by the security guard. Well dressed and meticulous about his duties, he exemplified what has become a national occupation, one that is an integral part of the country's outbound labour migration with roots in the tradition of Gurkha recruitment. It became our custom to exchange a few pleasantries every morning, and on one occasion he asked about the project on which I was working. I explained that it was a research project on ICT and rural development, to which he retorted, "ICT, ICT, everyone is talking about ICT nowadays." Grinning (and visibly proud of his ability to successfully construct a pun in English) he held a rather grimy porcelain tea cup to his eye, pointed to it, and quipped "Well, I see tea too, but you don't see me making such a fuss."

The comments of the security guard reflect a wider sense of suspicion and even disillusionment. The promise and potential of information and communications technology (ICT) has been the subject of much attention, many passionate speeches and lavishly funded programmes. However, there also appears to be widespread recognition that all of this is somehow not what it seems, that the promises of ICT are superficial, if not disingenuous, and certainly well beyond what anyone actually expects to materialise.

In the education sector, interest in the potential of ICT to transform education in low-income countries is particularly strong. Its proponents argue that new technologies offer an effective and equitable means to expand access, improve educational quality, and increase efficiency. Looking to theories such as constructionism (Papert and Harel, 1991), they further claim that ICT supports project-based, collaborative approaches to learning, instilling critical thinking and problem solving skills that will prepare students to compete in the global knowledge economy. Organizations such as the One Laptop Per Child (OLPC) Foundation, which aims to provide all children in low-income countries with one of its low-cost educational laptops, have generated widespread popular interest and support, adding momentum to "ICT for Development" or "ICT4D" movement. However, few of the claims about ICT's educational benefits have been substantiated empirically. At best, supporters can point to successful pilot studies or other small scale programmes; while at worst their position could be considered unfounded speculation. Given this disconnect between theory and empirical research, critics might well argue that support for ICT stems from an unfounded, ideological belief in technology.

In many respects, Nepal presents an ideal test case to evaluate the arguments for ICT in education. Its cash-strapped and over-burdened education system struggles to provide basic education and has little capacity to adapt to the changing demands of the twenty-first century. Similarly, the mountainous geography favours investments in communications technology over physical infrastructure (e.g. roads and bridges). Finally, the very strong presence of the international development sector and vibrant community of non-governmental organizations (NGOs) provides the capacity to implement programmes using ICT for education.

In this article, I analyse and critique the discourse on ICT for education in Nepal, arguing that support for ICT in policy and practice is largely driven by ideological motivations and the influence of technology as an indicator of progress. Policies on ICT in education reveal an uneasy and fragmented engagement with global discourses, offering surface-level support for expanding ICT but lacking a substantive agenda and clear rationale for doing so. These policies fit awkwardly with reform initiatives that look to conventional measures to expand access and improve quality (e.g. 
school construction, teacher training and administrative reform), and as a result most use of ICT in practice has come through the work of non-governmental organisations (NGOs) or in private schools. While they offer many examples of innovative adaptations of ICT, they are generally so limited as to cause little substantive change. Ultimately, in both policy and practice the importance of ICT is more due its power as symbol of modernity and development than any utilitarian or pragmatic value.

I begin by examining the theoretical underpinnings of ICT in international development and education and then look at how global discourses on ICT have unfolded in Nepal, juxtaposing the confused nature of government policy with the practice of local NGOs and schools. Finally, I assess how the discourse on ICT relates to the larger ideologies of modernity and development in Nepal.

\section{ICT and Development}

The study of technology, communications, and development dates to the work of modernization theorists such as Schramm (1964), Lerner (1958) and McLelland (1961). Correlating the presence of communications infrastructure (e.g. radios, televisions, and print media) with economic growth, they posited information access as a key requirement for a modern, or "achieving," society. Schramm (1964, p. 20 - 21) claims "no one who has seen modern communication brought to traditional villages will ever doubt its potency." Speaking of families in the Middle East, he describes access to radio as "a magic carpet to carry them beyond the horizons they had known." While this is certainly significant as one of the first articulations of the case for ICT in development, through the hackneyed allusion to magic carpets it also supports Said's (1979) contention that the production of academic knowledge about the orient (or in this case, "traditional villages") is complicit in maintaining relationships of international political domination.

At roughly the same time, Machlup (1962), Drucker (1968), and Bell (1974) developed the closely related concepts of the "information society" and "knowledge economy" in which an increasing share of social and economic relationships centres on the production and transfer of information rather than material goods. This prescribed investment in technical education in order to achieve integration into the global trade of knowledge and information. In this "investment approach," technology in education is treated as a specialised or concentrated allocation of resources; while it is at odds with the perceived need for mass basic education, it serves the greater good of economic growth through the development of human capital. This logic was pervasive for most of the latter twentieth century, and as a result of the need to ensure maximum returns on investment in technology, its use has often been reserved for higher, vocational, or technical education while basic education continues to use traditional methods (i.e. teachers and textbooks).

The history of modern India provides an example of the "investment approach:" the 1950s and 1960s saw heavy investment in technology in higher education, with the establishment of the elite and highly selective Indian Institutes of Technology and a growth of computing facilities at national universities. This came at a time when the basic education system was struggling, with gross primary enrolment rates at just $42.6 \%$ in 1951 (Kamat, 2007 p. 220). However, this investment yielded returns in the country's ability to develop technology for its own development and eventually compete in the global knowledge economy. For example, in the 1970s an Indian government research centre developed a telephone exchange that was considerably cheaper than those that the state-owned telephone company had been importing from the Unites States, and they were better 
suited in India's hot and humid climate (James, 2003). Investments in technical education also helped to fuel the explosive growth of India's multi-billion dollar software industry, which has created a new sector of middle class jobs and revolutionized life in many cities (D'Costa, 2003).

Despite this apparent success, it remains very dubious whether this model is replicable and sustainable, or confined to a very particular set of historical circumstances. India began its educational "investment" over a decade before Drucker's work on the "knowledge economy" and only managed to reap returns on its investment through the combination of a dramatic growth in the global demand for computer software, advances in communications technology, and trade liberalization policies. The lack of similar success stories around the globe hints at the inherent limitations of approaches to ICT in education that are based solely on a human capital approach.

In recent years, the argument for ICT in education has changed, shifting from human capital and economic growth to equity, social inclusion and access to basic education. Falling hardware costs, trade liberalisation and the growth of global communication networks, have given rise to speculation that ICT can contribute to education at all levels, even in the world's poorest communities. This has been accompanied by a shift in development priorities from economic growth through industrialization to poverty alleviation and capabilities (Sen, 1999), emphasizing basic education, civic participation, and economic opportunities for disadvantaged groups. Rather than a gateway to the global knowledge economy, ICT is viewed as a means to expanding educational access and quality. As articulated in the Tunis Commitment of UNDP's World Summit on Information Society,

ICTs have enormous potential to expand access to quality education, to boost literacy and universal primary education, and to facilitate the learning process itself, thus laying the groundwork for the establishment of a fully inclusive and development-oriented Information Society and knowledge economy which respects cultural and linguistic diversity. (World Summit on Information Society, 2005)

This conception of ICT essentially inverts the trade-off between expansion of mass education and investment in educational technology: rather than a concentrated investment with relatively few beneficiaries, ICT is actually posited as a cost-effective means to expand access to all.

\subsection{Critiques of Technology and Development}

While the discourse surrounding technology and development appears lofty and idealistic, on closer inspection there are many unanswered questions and perhaps fundamental flaws in its reasoning. The Tunis commitment (quoted above) elaborates at length on the benefits of ICT in education, it concentrates on the presupposed potential or theoretical benefits of ICT rather than presenting evidence that supports its claims. This lack of empirical justification is common to work on ICT in education; the argument is based mainly on theories or assumptions about what ICT can do rather than empirical evidence of what it actually does.

Even in relatively affluent countries, where the use of ICT in education is more prevalent and better studied, research has yet to produce any definitive, replicable findings on its benefits. For example, in an extensive study of technology in Californian schools, Larry Cuban (2001, p. 133) found "no clear and substantial evidence of students increasing their academic achievement as a result of using information technologies," and his ultimate conclusion that "the investment of billions of dollars 
over the last decade has yet to produce worthy outcomes" (p. 197) should serve as a poignant warning for future work. Other studies, have found that any benefits associated with ICT are highly contingent upon how technology is used and that effects and vary greatly according to age, gender and socioeconomic status (Wenglinsky, 1998; Atwell and Battle, 1999). As a result, some have argued that educational technology is driven by supply-side mechanisms that aim to create new products rather than meet demonstrated educational needs. In Laurillard's (2008, p. 139) words,

Education has problems. Technology has solutions looking for problems. The two should fit...but the solutions technology brings...are solutions to problems education does not have.

One explanation for these unsuccessful outcomes is the set of assumptions, values, and ideologies that often accompany the use of technology in education. These include an emphasis on rationality and belief in social progress that find their roots in the Enlightenment, in particular the belief that it

is "possible to understand the social world rationally and on that basis to 'improve' it" (Dale, 2005, p. 121). The concepts of rationality and progress are central to the case for ICT in education, which creates a logical framework of deterministic links between theories of learning and society, educational outcomes, and social change. However, the logical links that hold this together often fail to materialize in practice (or are far more complicated than anticipated), and the pursuit of technological solutions to educational problems seems to become a form of unreasoned reason.

The same critical examination of rationality is central to post-modern critiques of international development, which argue that development is a form of ideological colonization that endows the superiority of capitalist societies with the status of uncontested, ahistorical and universal truth. Building upon the work of Foucault and Said, ideological critiques of development (e.g. Ferguson, 1985, Escobar, 1995, Feenberg, 1995 and Rist, 1997) identify a regime of representation and a system of knowledge in which alternatives to capitalist societies are portrayed as deficient and to remedy this are prescribed a series of technical interventions. Thus, Escobar's (1995, p.162) contention that "development is about growth, about capital, about technology, about becoming modern. Nothing else" suggests that the transfer and adoption of educational technology is also the imposition of certain forms of economic logic that prioritise economic production and capital accumulation over all other concerns.

\section{Education and Technology in Nepal}

\subsection{ICT in State Education}

Mass education arrived comparatively late in Nepal, it was not until the country's first flirtation with democracy in the 1950s that a national education system was established. Early efforts to expand education were built around the three pillars of literacy, vocational preparation, and citizenship (National Education Commission, 1955). The last of these was of particular importance in the government's efforts to construct a national identity in an ethnically and linguistically diverse country. Furthermore, growth in enrolment took precedence over quality in the drive to rapidly expand basic education throughout the country. Writing in 1968, Reed and Reed described how, "Nepal's energies are turned toward proliferation of schools, while improvement of quality through increased competence in teaching and administration lacks adequate national support" (p. 160). 
Despite the focus on school construction and teacher training, the Ministry of Education and Sports (MoES) was an early adopter of distance education through radio: state-owned Radio Nepal began to air educational youth programming as early as 1957 (Ministry of Education and Sports, 2006). Following the transition to a Panchayat1 system of government in 1961, the rapidly growing medium of radio became pivotal in the government's effort to construct a shared Nepali identity in the diverse country. This included hiring songwriters and musicians to create a new body of lok git (folk songs) such as "Panchai Ho Yo Des Banaideu" ("Panchas, build the country") to promote the use of the Nepali language and commitment to the national development agenda (Parajulee, 2007). In 1973, a radio education program based on the formal primary curriculum was launched, complete with self-study materials. With funding from USAID, the Radio Education Teacher Training Program began in 1978 to address the shortage of qualified teachers in rural areas; this continued for five years and ultimately produced over 4,000 qualified teachers (Ministry of Education and Sports, 2006).

Following the democratic revolution of 1990, developments in education policy focused on capacity building and reform of the education sector to expand access to basic education. In just eight years, enrolment at the primary level increased 25\% (Central Bureau of Statistics, 2003). Equity and inclusiveness were also given greater attention: girls' enrollment grew by $65 \%$ in the same time period, and the Ninth Five Year Plan (Nepal Planning Commission, 1997) included provisions for mother-tongue education. However, due to funding constraints the use of ICT would have been at odds with the larger goal of expanding access to basic education. Thus, key initiatives and policies in educational development and reform (e.g. the Educational for All Action Plan, Basic and Primary Education Program I and II, and Community School Support Project) contain no mention of ICT.

More recently, the subject of ICT in education has begun to surface in policy documents. However, the rationale for using ICT is poorly defined and the outcomes are unrealistic. The Tenth Five Year Development Plan sets a goal to

Assist in expanding education suitable to the modern world by utilising computer literacy at all levels of education; and teach the subjects related to information and communication technology in the schools (Nepal Planning Commission, 2002)

It goes on to claim that ICT in education will "make the country competitive at the international level and direct it towards economic development" (Nepal Planning Commission, 2002, p. 448). Thus, the Plan looks to ICT as a path to modernization and global economic competitiveness. However, it does so by setting a goal of "utilising computer literacy," which Goodson and Mangan (1995, p. 65-66) critique as a "poorly defined and delineated... ideological concept, whose fuzziness and internal contradictions frequently serve to mask the social, political, and educational agendas of its proponents." In this case, the proponents are the educational policy makers, who are trying to sell their current policy packages as a progressive, modern and viable path to national development.

1 The Panchayat is a system of consensus governance by a five (panch) member council. Between 1960 and 1990, Nepal implemented the Panchayat system on a national level: the king was advised by a five-member council whose members were indirectly elected, while political parties were outlawed. Whelpton (2005) points out that in reality the national Panchayat had real little power. 
Unfortunately, the argument for computer literacy is so poorly reasoned and unsubstantiated that it is unlikely to lead to the desired international competitiveness and economic growth.

Several subsequent policy documents devote increased attention to ICT and focus more on educational quality than economic competitiveness, but they also reveal a similar inconsistency and incoherency in their approach. The 2002 Secondary Education Sector Plan calls for "increased use of information and communication technology for education management and delivery" (p. 35), while the National Curriculum Framework of 2005 describes a "need for ICT" on the grounds that it "is proven as a tool for educational transformation." Thus, the argument for ICT is reconstituted around the goal of social service delivery and educational quality; however, both the terms used and the reasoning behind them are vague at best (How will technology be used in delivery? On what evidence is ICT a "proven tool?"). Ironically, the 2005 National Curriculum Framework also concedes that ICT remains "wishful thinking for most schools in Nepal" (Curriculum Development Centre, 2005 , pp. 17, 30). While the rationale for ICT shifts from global competitiveness to education delivery, these policy documents continue to argue vehemently and without sufficient justification that ICT is required in mainstream education.

Recently, the discourse around ICT in education has changed yet again to more closely align with ideals of equity and inclusiveness found in the WSIS Tunis Commitment. The Ministry's Open and Distance Learning Framework (2006) proposes the use of ICT to "act as alternative [sic] to existing conventional education system in order to ensure fuller access of all interested learners belonging to various groups especially poor, women, deprived, marginalized citizens to education" (p. 7). The plan also contains goals for open (i.e. license-free) learning materials, support for self-study learners, and an increase in technical and vocational qualifications available to open and distance learners. By returning to the distance education strategy of Radio Nepal in the 1950s and 60s, the government has adopted an emphasis on equity and inclusion from the global discourse on ICT and education. In order to facilitate the Tunis Commitment's ideal of "a fully inclusive and development-oriented Information Society," the tenth five year plan sets a goal to establish 1,500 telecentres throughout the country (Nepal Planning Commission, 2002), but does not specify who will undertake this task or how it will be funded.

The continual shifts and adjustments in the government's approach to ICT in education suggest an overall state of policy confusion. At various times, global economic competitiveness, improved educational quality, and expanded access to education among marginalized groups have all served as rationales for investments in educational ICT. In some cases, the approach to ICT has come closer to political propaganda than education policy. For instance, in a strange variation on the Jomtien Declaration, the Information Technology Act of 2057 (2000) promises "Computer Education for All by 2010 " but gives no reason for why this is important or how it would be accomplished. Perhaps as the result of its prominence in the international sphere, there is simply a perceived need to formulate some agenda for ICT in education. Whatever the reason, the result is an ill-fitting combination of goals and strategies that have little logical coherence nor realistic prospects of success.

\subsection{ICT in Practice: Civil Society and the Private Sector}

While national policies on ICT in education provide nominal direction and support for ICT in education, in practice there are virtually no state-funded ICT programmes in government schools. 
Whatever use of technology exists in practice comes either through programmes run by NGOs or in the highly-competitive (and highly controversial) private schooling sector. NGOs are often among the first to embrace new educational practices and technological innovation (Chabbott, 2003). Evidence of this tradition can be found in the innovative educational programs of community radio stations and village newspapers in the 1990s (James, 2005). Additionally, the rapid and uncontrolled growth of the private sector (Carney and Bista, 2009) has created intense competition among private schools, and ICT is one means for schools to differentiate themselves from one another.

The number of NGOs running programs that use ICT for education has grown rapidly in recent years, a recent study counted over twenty educational programs that use ICT (Shields, 2008). These range from infrastructure-oriented projects that provide schools with computers and/or connection to the internet (often through very innovative means) to those that create and support educational content and services. Others attempt to do both, for example the aforementioned OLPC programme provides hardware (i.e. low-cost laptops) as well as its open-source operating system that aims to facilitate educational collaboration. Finally, many programmes run by NGOs are not specifically focussed on education but fall under the much broader bracket of information access and ICT services (which themselves have educational implications). Supported by the government's goal to establish 1,500 telecentres many NGOs have created variations on the concept of the telecentre model, providing access to a variety of ICT services, the most important of which is arguably access to the internet.

Many of these programmes yield tangible benefits that are widely desired by beneficiaries: access to information and communication facilitates critical inquiry and examination of social power structures that call to mind Freire's (1972) concept of conscientization. However, there are legitimate questions as to whether any of these programmes will bring substantive change to formal education in Nepal. While ICT is ostensibly used to meet a demonstrated educational need, many programmes seem more intent on showcasing new forms of technology or transferring existing technologies to the education sector. Much of this is attributable to the fact that NGOs themselves operate in a competitive environment where the ability to attract funding is largely determined by the demonstration of innovative, ground-breaking program models. The result is a perpetual series of supply-driven pilot programmes, each promising the ability to "scale up" and revolutionise education across, but operating in a competitive "market" for innovation that effectively ensures this will never happen.

Like civil society organisations, private schools have been more proactive in adopting ICT than their state-run counterparts. This comes as little surprise: private schools have larger budgets, more discretion over how funds are used, and operate in a competitive environment where technology is another means to differentiate a school from its rivals. ICT is in widespread use among the country's better-funded private schools, particularly in the Kathmandu Valley and other urban centres. Because of differences between individual schools, the strategy for the use of ICT in private schools varies considerably, and in some cases technology in schools may be no more than a marketing ploy, as demonstrated by the brochure for a private school in Pokhara advertising "high-tech facilities" and a "well equipped computer lab" without mentioning how they are used. However, as current initiatives to expand privatization of schooling may result in increased competition in the education sector (Carney and Bista, 2009), more private schools may turn to ICT as a way to woo their prospective "clients." 
In addition to private schools, a large number of internet cafes serve a double purpose as selfdescribed "computer training centres." These unregulated enterprises can be found even in relatively small towns and offer basic "computer literacy training" (i.e. how to use a computer for basic tasks such as word processing). A 2005 report from the High Level Commission of Information Technologies counted more than 1,000 private ICT training institutes across the country, giving evidence of a strong demand for non-formal ICT training. Ironically, there is little empirical evidence to demonstrate that such training yields economic returns or improved employability. Rather, competency in ICT identifies one with a particular set of modernist values that Stacey Pigg (1992) identifies as bikaas (the Nepali word for "development"). According to Pigg, bikaas is both an "imagined national community" and a "compass point according to which socially located people orient themselves" (Pigg, 1992, p. 499). Along with other patterns of consumption and competencies (e.g. popular music, Western clothes, and the English language), access to and training in ICT associates one with concepts of modernity, progress, and bikaas, essentially making it akin to what Inkles (1983) describes as "individual modernity."

\section{Ideology and Symbolism: ICT as a modernist discourse}

While government policies on education consistently stress the need for ICT, there is an inconsistency and incoherence in their rationales for doing so. Instead of an authentic, self-identified justification, ideas such as economic competitiveness, "computer literacy" and social equity are borrowed from the continually changing global discourse on ICT and development. These terms and concepts endow the national education system with a certain legitimacy and respectability, showing that it progressive and modern while simultaneously avoiding the need for a national strategy on ICT in education that can stand up to close scrutiny.

Ham and Cha's (2009) recent study on the adoption of national policies on ICT in education offers one analysis of policy diffusion that might explain the peculiarity of Nepal's experience. Using a sample of 134 countries, they look at how variations in national context (e.g. ICT infrastructure, gross domestic product and the presence of intergovernmental networks) predict whether or not countries formulate policies on ICT in education in two time periods (1981-5 and 1991-5). In this framework, whether or not a country like Nepal adopts could be explained (to some extent) by the values of these variables.

However, their regression analyses arguably do more to problematise the adoption of ICT policies than to explain it. Of the eleven variables included in their analysis, only one (the number of scientific and technical publications) was statistically significant in both time periods, suggesting that there are few national properties that inevitably lead to the adoption of such policies. Others variables more closely linked to formal education and ICT (e.g. educational expenditure and internet infrastructure) were not statistically significant and even had opposite effects (i.e. differing negative/positive coefficients) in the two time periods. Perhaps the greatest obstacle to the analysis is the treatment of ICT policy adoption as a binary (dichotomous) variable: in the analysis, policies on ICT are either present or not, there are no shades of grey nor directionality of influence that might explain the incoherent and conflicting policies found in Nepal.

All this indicates that the adoption of policies on ICT is less determined by measurable properties of the national context than by the transfer of certain political ideologies. A national policy on ICT in education is not a discrete entity which is either present or not, but rather a manifestation of global 
ideologies in a particular context. Whether or not a national government forms policies on ICT is only a small part of this picture, just as important is how a country forms its policies, including the translation of global ideologies into national contexts and the extent to which these policies "model themselves after other countries that are perceived to be successful or legitimate" (Ham and Cha, 2009 , p. 552). Unlike the transfer of other educational policy packages to Nepal, for example the decentralization measures described by Carney (2009), this process does not take the form of "a policy script dictated from outside to politically astute central actors" (Carney, 2009, p. 80). Rather, these political elites emulate the global discourse from their own self-interest, which is inevitably furthered by an association encapsulating education, technology, and modernity.

In contrast to the policy arena, the use of ICT in educational practice is more nuanced and complex. While ICT in state education is essentially limited to the realm of policy, programmes run by NGOs have shown the ability to innovate and engage with ICT in a sophisticated ways. In many senses this contrast between policy and practice reflects Warschauer's $(2004$, p. 36) juxtaposition of teachers' "grassroots" efforts to experiment and effectively utilise ICT with the authoritarian and politically motivated agenda of development donors. Particularly in the case of NGOs, the "grassroots" label seems appropriate due to the innovative ways in which organizations adapt ICT to perceived local needs. However, this innovation occurs within a politically-motivated context: NGOs operate in a marketplace for development funding in which innovation and local impact are "products" that are in demand. Private schools are even more directly market oriented, and ICT is arguably more important for its ability to attract student-consumers than for its educational value. While they are very different in many respects, for both NGOs and private schools, a significant portion of the value of ICT is its symbolism.

While there are considerable differences between policy and practice, both share a common set of assumptions about education, technology and development. All involved agree that there is a need for development in Nepal, that there is a set of identifiable, discrete social problems or deficiencies that can be systematically addressed through education. Additionally, there is agreement that ICT can significantly improve the efficiency or effectiveness of educational interventions in delivering desired social changes. Thus, perceived social problems are reformulated as technological problems, and deficits in society essentially become deficits in technology.

This shared understanding of ICT, education and development is quintessentially modernist in its orientation. Centred on what Ferguson (1985) calls the "instrument-effects" model, it establishes rational, determinist links between progress towards social goals and a series of systematic social interventions. ICT is a means to an end and a cog in a larger ideological machine; its invocation (whether in policy or practice) carries an associated set of values that centre on progress through development and modernization.

However, in addition to these modernist ideologies, ICT has another symbolic value that relates less to determinist perspectives on social planning and development than to the formation of an imagined community of institutions and individuals around the ideals of modernity and progress. Much of this is captured in Pigg's concept of bikaas, "an implicit scale of social progress" through which individuals, places, and organizations are identified as progressive and modern (Pigg , 1992, p. 499). Both education and ICT are key signifiers of bikaas: The former "is both a symbol of bikaasi status and the route through which people can hope to move from farming in the village to an office 
job in a bikaasi place" while the latter conforms to the pattern that "bikaas comes to local areas from elsewhere; it is not produced locally. Most material aspects of bikaas....are manufactured" (Pigg, 1992, pp. 499-502).

Ironically, this symbolic value of ICT in education has become even more powerful than the "instrument-effects" vision of social planning and development that underlie it. As suggested by Pigg's work, the semiotic nature of modernity and development is complex and pervasive. For instance, writing in 1968, Reed and Reed attribute a symbolic value to education itself, arguing teachers "do not teach that symbols are tools for solving personal and national problems...Nepalis learn symbols for the sake of symbols" (p. 102). Technology in education has essentially become another "compass point" through which individuals (whether students, teachers or policy makers) and institutions construct modern and progressive identities. In contrast to the dominant international discourse (that technology has pragmatic value because it can measurably improve educational performance), the Nepali experience of ICT in education shows that much of its power and appeal is not to do with its educational utility or ability to affect change, but rather in a shared cultural symbolism that stems from larger power structures and ideologies of the development encounter.

\section{Conclusion}

I have argued that ICT policies and practices in education in Nepal are largely symbolic and ideological, showing that they share a common association of technology with modernist notions of progress and development. Nepal's experience with ICT in education shows that symbols of modernity are often just as powerful as the instrumental forms of planning that underlie them. Furthermore, even when these underlying rational frameworks unravel or disintegrate (as has happened in the case of policies on ICT in education), symbols of modernity persist independently.

This raises the question of what is next for ICT and education in Nepal, to which I suggest that the answer is probably "more of the same." On one hand, ICT is unlikely to come to the forefront of educational policy debates, which will likely focus on areas where donor interest is strongest (i.e. decentralisation, access, and institutional reform). In turn, these educational policy debates will also be overshadowed by larger national political issues such as territorial autonomy. On the other hand, the rapid succession of governments and continuing political instability suggest that any government will need to legitimise itself to the electorate, development donors, and political parties alike. Invoking a bikaasi vision of education and development is a low-cost, high-returns way to project this vision, and, therefore, the creation of uninformed and poorly reasoned policies on ICT in education is likely to continue.

The larger engagement with technology and development will involve a dialectic of global trends and local adaptation, but the latter may become more prominent. Throughout the "People's War," the Maoist army relied heavily on technology (e.g. satellite phones and the internet) to maintain communication between its disparate, clandestine guerrilla units, and they may well have been the first revolutionary movement to create its own website. To the extent that they are involved in Nepal's future government, the Maoists could bring a pragmatic and in-depth understanding of how technology can be used as a means to an end (rather than an end in itself). However, any attempt to use technology to further their goals of class equality and empowerment of disadvantaged groups will have to be accomplished in a telecommunications sector that (like education) is increasingly 
privatised and caters largely to relatively affluent consumers in urban centres (Shields, 2009). Whether or not the promise of a "fully inclusive and development-oriented Information Society" ever truly materializes, the success of ICT in education will be measured as much by a process of informed national dialog and critical reflection as by expanded access and economic competitiveness.

References

Atwell, P., \& Battle, J. 1999. Home Computers and School Performance. The Information Society, 15, $1-10$.

Bell, D. 1974. The Coming of Post-Industrial Society: A Venture in Social Forecasting. London: Heinemann.

Carney, S. 2009. Negotiating policy in an age of globalization: Exploring educational "policyscapes" in Denmark, Nepal, and China. Comparative Education Review, 53(1), 63-88.

Carney, S., \& Bista, M.B. 2009. Community Schooling in Nepal: A Genealogy of Reform Since 1990. Comparative Education Review, 53(2), 189 - 211.

Chabbott, C. 2003. Constructing Education for Development: International Organizations and Education for All. New York: Routledge Falmer.

Cuban, L. 2001. Oversold and Underused: Computers in the Classroom. Cambridge: Harvard University press.

Curriculum Development Centre. 2005. Nation Curriculum Framework for School Education (Preprimary-12) in Nepal. Kathmandu: Ministry of Education and Sports.

Dale, R. 2005. Globalisation, knowledge economy, and comparative education. Comparative Education, 42(1), $117-149$.

D'Costa, A.P. 2003. Uneven and combined development: understanding India's software exports. World Development 31(1), $211-226$.

Drucker, P. 1968. The Age of Discontinuity: Guidelines to Our Changing Society. New York: Harper \& Row.

Escobar, A. 1995. Encountering Development: The Making and Unmaking of the Third World. Princeton, New Jersey: Princeton University Press.

Feenberg, A. 1995. Alternative Modernity: The Technical Turn in Philosophy and Social Theory. Berkley: University of California Press. 
Ferguson, J. 1985. The Anti-Politics Machine: "Development," Depoliticization, and Bureaucratic Power in Lesotho. Minneapolis: University of Minnesota Press.

Freire P. 1972. Pedagogy of the Oppressed. London: Penguin.

Goodson, I.F. \& Mangan, J.M. 1996. Computer literacy as ideology. British Journal of Sociology of Education, 17(1), $65-79$.

High Level Commission on Information Technology. 2005. A Factbook on Information and Communications Technology Sector of Nepal (sic). Kathmandu: Ministry of Science and Technology.

Inkles, A. 1983. Exploring Individual Modernity. New York: Columbia University Press.

James, J. 2003. Bridging the Global Digital Divide. Cheltenham: Edward Elgar Publishing.

Kamat, S.G. 2007. Walking the tightrope: Equity and growth in a liberalising India. In R. Teese, S.Lamb, and M. Duru-Bellat (Eds.), International Studies in Educational Inequality, Theory and Policy.

Lerner, D. 1958. The Passing of Traditional Society: Modernizing the Middle East. Glencoe: The Free Press.

Laurillard, D. 2008. The teacher as action researcher: using technology to capture pedagogic form. Studies in Higher Education 33, no. 2, pp.139-154.

Machlup, F. 1962. The Production and Distribution of Knowledge in the United States. Princeton: Princeton University Press.

McClelland, D.C. 1961. The Achieving Society. Princeton: D. Van Nostrand.

Ministry of Education and Sports. 2006. Open and Distance Learning (ODL) Policy Framework. Kathmandu: Author.

Ministry of Education and Sports. 2002. Secondary Education Sector Plan: Core Document. Kathmandu: Author.

National Education Commission. 1955. Report of the National Education Commission. Kathmandu: National Education Commission.

Nepal Planning Commission. 1997. Ninth Five Year Plan. Kathmandu. 
Nepal Planning Commission. 2002. Tenth Five Year Plan. Kathmandu.

Papert, S., \& Harel, I. 1991. Constructionism. Norwood: Ablex Publishing Corporation.

Parajulee, S. 2007. Seven decades of radio listening in Nepal. Westminister Papers in Communication and Culture 4, no. 2.

Pigg, S.L. 1992. Inventing social categories through place: Social representations and development in Nepal. Comparative Studies in Society and History 34(3), 491-513.

Rist, G. 1997. The History of Development: From Western Origins to Global Faith. London: Zed Books

Said, E. 1979. Orientalism. New York: Vintage Books.

Schramm, W. 1964. Mass Media and National Development: The Role of Information in the Developing Countries. Stanford: Stanford University Press.

Sen, A. 1999. Development as Freedom. New York: Knopf.

Shields, R. 2008. False Summit or Final Peak? Education, Information Technology, and Development in Rural Nepal. Unpublished doctoral dissertation, University of California, Los Angeles.

Shields, R. 2009. The landlocked island: Information access and communications policy in Nepal. Telecommunications Policy, 33(3-4), $207-214$.

Waschauer, M. 2004. The rhetoric and reality of aid: promoting educational technology in Egypt. Globalisation, Societies and Education, 2(3), 377 - 390.

Wenglinsky, H. 1998. Does it Compute? The Relationship Between Educational Technology and Student Achievement in Mathematics. Princeton: ETS Policy Information Center.

Whelpton, J. (2005). A History of Nepal. Cambridge: Cambridge University Press.

World Summit on Information Society. 2005. Tunis Commitment. Document WSIS-05/TUNIS/DOC/7E. United Nations World Summit on Information Society, 16 - 18 November, 2005, Tunis, Algeria. 